[Radiocarbon, Vol. 12, No. 2, 1970, P. 400-420]

\title{
BERLIN RADIOCARBON MEASUREMENTS IV
}

\author{
G. KOHL and H. QUITTA
}

Central Institute of Ancient History and Archaeology, German Academy of Sciences in Berlin, German Democratic Republic

This list includes selected dates of archaeologic samples from DDR, Czechoslovakia, Hungary and the Soviet Union made between 1966 and 1969. As in previous lists the major portion of dates are concerned with Neolithic and Early Bronze age period in Middle and SE Europe.

The dating method, counting technique, and equipment is the same as described in Berlin III (Radiocarbon, 1969, v. 11, p. 271-277). Ages are given relative to A.D. 1950 and the half-life of $5568 \pm 30 \mathrm{yr}$ has been assumed. Age errors include counting errors of samples, background, and standard, and error in the half-life of $\mathrm{C}^{14}$. Errors smaller than $100 \mathrm{yr}$ have been increased by rounding to that figure as a minimum. Dates are not corrected for isotopic fractionation. The descriptions are based on information supplied to the authors by the submitters and on the publications referred to under each sample or series.

\section{ACKNOWLEDGMENTS}

Thanks are extended to M. Leu and E. Mann for assistance in preparing and measurement of samples, and G. Kuckelt for maintaining the electronic equipment. We also want to thank M. Hopf, Römisch-Germanisches Zentralmuseum, Mainz, for botanical determinations.

\section{SAMPLE DESCRIPTIONS \\ A. German Democratic Republic}

$4065 \pm 80$

\section{Bln-533. Dornburg}

2115 B.c.

Charcoal (Quercus sp.) from late Neolithic burial mound near village Dornburg ( $51^{\circ} 0^{\prime} \mathrm{N}$ Lat, $11^{\circ} 39^{\prime} \mathrm{E}$ Long), Jena Co., Gera Dist. Burial mound (nearly $2 \mathrm{~m}$ high, base diam. $16 \times 18 \mathrm{~m}$ ) used a built-in wooden structure (mortuary house) surrounded by fascine-revetted stone wall. Sample from burnt remains of wooden structure at depth 1.50 to $1.60 \mathrm{~m}$ below mound surface in ash layer under Grave $1 \mathrm{~b}$ (Peschel, 1963). Archaeol. dated to Mansfeld group of developed Central German Corded Ware culture. Coll. 1960; subm. by K. Peschel, Inst. for Praehist. Arch. of Fr. Schiller Univ., Jena. Comment: Bln-533 appears considerably older than earlier Heidelberg-date from burnt fascine fence of same burial mound $(\mathrm{H}-2123 / 1538$ : $3745 \pm 60)$. As there are no doubts as to the simultaneity of the whole burial complex, the difference may be based on the different sample material (thin tree branches of fascine and compact oak planks of the mortuary house). Other $\mathrm{C}^{14}$ dates of the Mansfeld horizon of the Saxonic-Thuringian Corded Ware culture (Etzdorf, Halle/ Heide, Forst Leina), are between 1990 and 2200 B.c. 
Bln-838. Halle-Dölauer Heide

$4105 \pm 100$

2155 B.c.

Charcoal detritus and carbonized soil from late Neolithic site at Dölauer Heide (Bischofswiese) near Halle $\left(51^{\circ} 31^{\prime} \mathrm{N}\right.$ Lat, $11^{\circ} 35^{\prime} \mathrm{E}$ Long), Dist. Halle. Sample from $0.40 \mathrm{~m}$ deep pit, underlying $1.20 \mathrm{~m}$ high Barrow 3 with graves of Corded Ware. Archaeol. assignment to Bernburg group of Funnel Beaker culture. Coll. June 1969; subm. by H. Behrens, Landesmus. f. Vorgeschichte, Halle. Comment: Bln-838 is younger than dates of Bernburg group of Aspenstedt (H 210/217: 4560 \pm 110) and Pevestorf (Hv-582: $4380 \pm 100)$. Contamination might have occurred by roots of oak forest that were observed down to pit ground.

\section{Bln-550. Löbnitz}

$3980 \pm 125$ 2030 B.c.

Charcoal and wood remains (Quercus sp.) from an earth-grave of Bell Beaker culture in Löbnitz (51 $51^{\prime} \mathrm{N}$ Lat, $11^{\circ} 42^{\prime} \mathrm{E}$ Long), Stassfurt Co., Magdeburg Dist. Sample originates from wooden coffin in grave pit of Tomb 1, $1.58 \mathrm{~m}$ below surface (Kaufmann, 1969). Coll. 1966 by B. Schmidt; subm. by D. Kaufmann, Landesmus. f. Vorgeschichte, Halle/S. Comment: Bln-550 is older than $\mathrm{C}^{14}$ dates of Bell Beaker culture in N Germany and Netherlands.

\section{BIn-817. Zwenkau-Harth}

$5890 \pm 100$ 3940 B.c.

Charcoal (Quercus sp.) from large Bandkeramik settlement in Harth forest near Zwenkau (51 $11^{\prime} \mathrm{N}$ Lat, $12^{\circ} 21^{\prime}$ E Long), Leipzig Dist. Sample from $0.80 \mathrm{~m}$ deep posthole of House II, belonging to late phase of Linear pottery (Quitta, 1958). Coll. 1953; subm. by H. Quitta, Berlin. Comment: sample of same house dated by Groningen lab (GrN-1581: $6160: \pm 70$ ). Bln-817 agrees very well with many dates of late Linear pottery from Central Germany.

\section{Bln-472. Gnewitz \\ $4250 \pm 100$}

Charcoal (Quercus sp.) from Passage Grave $2 \mathrm{SW}$ village Gnewitz (54 $4^{\circ} \mathrm{N}$ Lat, $12^{\circ} 31^{\prime} \mathrm{E}$ Long), Rostock Dist. Sample from E end of $8 \mathrm{~m}$ long chamber on the floor between skeleton remains. Although very few Neolithic sherds were found, amber beads indicate archaeol. assignment of burials to developed phase of Funnel Beaker culture. Secondary burials belong to Globular Amphorae culture and Single Grave culture (Schuldt and Wetzel, 1967). Coll. 1965; subm. by E. Schuldt, Mus. f. Ur- und Frühgeschichte, Schwerin. Comment: Bln-472 agrees with expected age.

Bln-432. Frauenmark

$4010 \pm 100$

Charcoal (Quercus sp.) from Passage Grave SE village Frauenmark (53 $47^{\prime} \mathrm{N}$ Lat, $11^{\circ} 47^{\prime} \mathrm{E}$ Long), Parchim Co., Schwerin Dist. Sample 
from $\mathrm{E}$ part of $7.70 \mathrm{~m}$ long chamber within thin loamy covered chamber floor (Hollnagel, 1967). Archaeol. assignment to Funnel Beaker culture uncertain; no ceramic finds assoc. with construction of monument. Scattered sherds of Single Grave and Bell Beaker culture were found near burial mound. Coll. 1965 by A. Hollnagel, Mus. f. Ur- und Frühgeschichte, Schwerin; subm. by excavator. Comment: date significantly differs from Bln-472 (Gnewitz) and other dates from Passage-Grave period; it must be assumed that megalithic tomb was secondarily used in late Neolithic time.

\section{Bln-473. Liepen}

$4080 \pm 100$

Charcoal (Quercus sp.) from Passage Grave $1 \mathrm{~N}$ village Liepen $\left(54^{\circ}\right.$ $4^{\prime} \mathrm{N}$ Lat, $12^{\circ} 31^{\prime} \mathrm{E}$ Long), Rostock Dist. Scattered charcoal fragments from floor of $6 \mathrm{~m}$ long chamber between skeleton remains. Because of no ceramic finds, archaeol. date uncertain. Assoc. with secondary burials, 2 vessels of late Funnel Beaker culture found in passage, which may belong to the end of the middle Neolithic period (Schuldt, 1967). Coll. 1965 by E. Schuldt; subm. by excavator. Comment: Bln-473 dates a secondary burial phase and not the construction of megalithic tomb.

\section{Rügen-series}

\section{BIn-560. Lietzow-Buddelin No. 1}

Charcoal (Fraxinus excelsior L.) from cross section at lower W slope

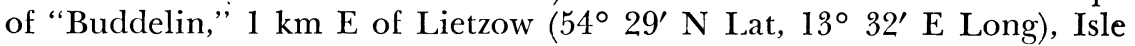
of Rügen, Stralsund Dist. Profile section shows following stratification: lowest boulder sands (1), overlain by $20 \mathrm{~cm}$ peat (2), topped by a 25 to $30 \mathrm{~cm}$ thick cultural layer (3) with numerous artifacts. Over them 10 to $20 \mathrm{~cm}$ coarse sand (4) and 30 to $50 \mathrm{~cm}$ younger peat layer (5), which in upper profile transitional to humic sands of the meadow ground. Sample from 1.10/1.40 m below surface of cultural layer (3) (Gramsch, 1966). Archaeol. dated on basis of typical flint tools (Kern- und Scheibenbeile) to "Lietzow group" of Ertebölle-Ellerbeck culture. Layers 2 and 3, based on pollen analysis (Lange, Berlin) to be assigned to the younger Atlantic Pollen Zone VIII, after Overbeck; the upper peat (5), to Pollen Zone XI. Coll. 1965; subm. by B. Gramsch, Mus. f. Ur- und Frühgeschichte, Potsdam.

\section{BIn-561. Lietzow-Buddelin No. 2}

Charred wood (Quercus sp.) from same sec. as Bln-560, from 1.70 to $1.90 \mathrm{~m}$ below surface of lowest boulder sands (1). Frequent flint artifacts, worked bone, and antler tools are remains of an older settlement of the Ertebölle-Ellerbeck culture. Some artifacts with slight rolling traces indicate a partially secondary stratification, which may be related to an oscillation of Scandinavian Transgression Phase L/II of Littorina Sea. 
The overlying peat (2) and the peat-containing cultural layer (3) had formed in a subsequent regression phase which includes the main settlement of the site (Gramsch, 1966). Coll. 1966; subm. by B. Gramsch.

\section{Bln-562. Ralswiek-Augustenhof}

$5455 \pm 100$

Charcoal (Quercus sp.) from cross section in Augustenhof low grounds near Ralswiek (54 $29^{\prime} \mathrm{N}$ Lat, $13^{\circ} 29^{\prime} \mathrm{E} \mathrm{Long}$ ), Isle of Rügen, Stralsund Dist. Profile Sec. L III/66 within the shore zone indicates following stratification: lowest marine sands, overlain by $25 \mathrm{~cm}$ humic sands, topped by $80-\mathrm{cm}$-thick layer transitional from muddy peat to peat, which is overlain by sandy-gravelly sediments of $1.25 \mathrm{~m}$ high beach wall (Strandwall). Sample from 1.80 to $2.10 \mathrm{~m}$ deep horizon with flint artifacts and charcoal remains, including uppermost humic sand and muddy peat layer (Gramsch, 1969). Coll. 1966; subm. by B. Gramsch.

General Comment: studies made by B. Gramsch, H. Kliewe, and E. Lange on Lietzow and Ralswiek (Isle of Rügen) sites for the lst time provides a correlation of the late Mesolithic/early Neolithic occupation with Holocene sea-level variations in S Baltic coastal region. Measurements correspond with settlement sequence and are in general agreement with other dates of Ertebölle-Ellerbeck culture known from the Baltic Sea coasts of Schleswig-Holstein, Denmark, and S Sweden.

\section{Bečov-series}

\section{B. Czechoslovakia}

At Bečov (50 $25^{\prime} \mathrm{N}$ Lat, $13^{\circ} 44^{\prime} \mathrm{E}$ Long), Most Dist., NW Bohemia, a workplace of Quarzit tools was excavated by J. Fridrich, Archaeol. Inst. Acad. Sci. Prague. Both samples consisted of scattered charcoal fragments from 2 pits, expected to belong to late Paleolithic time (Magdalenian). Coll. 1966 and subm. by excavator.

Bln-552. Bečov No. 1

$3480 \pm 80$

Charcoal (Quercus sp.) from Pit V, depth $2.00 \mathrm{~m}$ below surface.

\section{Bln-553. Bečov No. 2}

$3395 \pm 80$

Charcoal (Quercus sp.) from Pit I, depth $2.00 \mathrm{~m}$.

General Comment: both dates indicate that charcoal of settlement pits related to a later occupation of the site; datable archaeol. material was not found.

\section{Brno-Líšen-series}

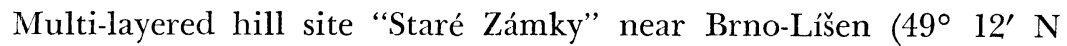
Lat, $16^{\circ} 42^{\prime}$ E Long), Brno Dist., Moravia. Cultural layer of thickness up to $3 \mathrm{~m}$ shows at lowest part, small finds of Moravian Painted Pottery (Lengyel culture), and above it 3 Eneolithic levels (Lišen III-I), followed by late Bronze age and Slavic occupation (Medunová-Benešová, 1964). 
Archaeol. dates to upper Eneolithic level Liššen I with finds of younger Channelled Ware (corresponding transition from Jevišovice $\mathrm{C} 1$ to $\mathrm{B}$ period). Coll. 1963; subm. by A. Medunová-Benešová, Archaeol. Inst. ČSSR, Acad. Sci., Brno.

\section{Bln-433. Brno-Líšen $1 / 63$}

$3925 \pm 150$

Charcoal Sample 1/63 (Quercus sp.) from level Líšen I, from Area PP-III/1963, $1.50 \mathrm{~m}$ below surface.

\section{Bln-434. Brno-Líšen 2/63}

$3035 \pm 150$ 1085 в.C.

Charcoal Sample 2/63 (Quercus sp.) from level Lišen I, from Area RR-III/1963, $1.20 \mathrm{~m}$ below surface. Comment: Bln-434 suggests that this sample, from upper horizon of Lišen I level, should be assigned to overlying late Bronze age settlement.

\section{Chabarovice series}

Neolithic settlements, for clecades endangered by brown coal open works, on ca. 100 acre loess area between Hrbovice and Chabařovice $\left(50^{\circ}\right.$ $40^{\prime}$ N Lat, 135 57' E Long), Ústí Dist., NE Bohemia. Rescue excavations of archaeol. Expositur in Most since 1959 furnished evidence for several Bandceramic sites. During those campaigns many settlement pits and several house ground plans, mainly incomplete, were uncovered (Kruta et al., 1966). Coll. 1964; subm. by V. Kruta, Archaeol. Inst. ČSSR, Acad. Sci. Prague.

\section{Bln-438. Chabarovice-48/B}

$6400 \pm 120$

Charcoal (Quercus sp.) from $\mathrm{N}$ part of settlement area, at 0.70 to $0.90 \mathrm{~m}$ below surface from lower parts of Pit 48/B which belongs to a more comprehensive pit system at E side of $40 \mathrm{~m}$ long house. Archaeol. dated to developed phase of the oldest Linear pottery.

\section{Bln-437. Chabarovice-58/A}

$5070 \pm 200$

Charcoal (Quercus sp.) from same area at 0.50 to $0.60 \mathrm{~m}$ below surface from Pit System 58/A at opposite W side of same house. Archaeol. dated as Bln-438. Pit system, consisting of 4 separate pits (A-D) is disturbed by a shallow pit with Stroke ornamented pottery.

General Comment: Bln-438 fits well with expected radiocarbon age for older Linear pottery (cf. Žopy Bln-57: $6430 \pm 100$; Eitzum H 1487/985: $6480 \pm 210)$. Bln- 437 is considerably younger, which may be caused through contamination with material of Stroke ornamented pottery (Stichbandkeramik) observed in the same pit system. 
Bln-304. Horné Lefantovce

Charcoal (Fraxinus sp.) from a Neolithic settlement in upper Nitra valley near Horné Lefantovce $\left(48^{\circ} 25^{\prime} \mathrm{N}\right.$ Lat, $18^{\circ} 10^{\prime} \mathrm{E}$ Long), Nitra Dist. W Slovakia. Foundations of 13 dome-shaped ovens, partly overlapping and closely grouped were discovered during rescue diggings on site "Na babe". Sample coll. from well-preserved Oven 6 at $0.70 \mathrm{~m}$ below surface (Banesz, 1959). Archaeol. assignment of oven system to late phase of Želiezovce group plus isolated sherds of Bükk and stroke-ornamented pottery. Coll. 1958 by L. Bánesz; subm. by J. Pavúk, Archaeol. Inst. Slovakian Acad. Sci., Nitra. Comment: Bln-304 appears considerably younger than middle stage of the Želiezovce group in Štúrovo (cf. Bln558: $6170 \pm 100$; Bln-559: $6260 \pm 100$ ). The actual time range between both stages supposedly is smaller.

\section{Bln-495. Hostim}

$2005 \pm 80$

Charcoal (Quercus sp.) from late Paleolithic site in valley of Berounka R. near Hostim (49 $57^{\prime} \mathrm{N}$ Lat, $14^{\circ} 7^{\prime}$ E Long), Beroun Dist., Bohemia. Sample in depth 0.35 to $0.50 \mathrm{~m}$ below surface from basal part of loess layer with burnt clay fragments and flint artifacts belonging to Magdalenian. Coll. 1965 and subm. by Sl. Vencl, Archaeol. Inst. Prague. Comment (S.V.): Bln-495 points to a secondary contamination by roots or to possibility, that scattered charcoal, owing to its position near surface, reduced to remains of a later forest-fire.

\section{BIn-302. Krepice \\ $3020 \pm 150$}

Grain (Hordeum vulgare L. polystichum) from settlement, fortified by palisade ditches, of the Lengyel culture in Křepice $\left(48^{\circ} 58^{\prime} \mathrm{N}\right.$ Lat, $16^{\circ}$ $6^{\prime}$ E Long), Znojmo Dist., S Moravia. Sample from nearly destroyed oven in upper part of a $3.50 \mathrm{~m}$ deep pit (Object 8 ) at ca. $0.60 \mathrm{~m}$ below surface (Tichý, 1966). Archaeol. dated to older stage of Moravian-Painted-Pottery (Lengyel culture). Coll. 1964; subm. by R. Tichý, Archaeol. Inst. ČSSR Acad. Sci., Brno. Comment: B1n-302 appears too recent in view of other chronologic evidence. It is more likely that grain finds, weighing several $\mathrm{kgs}$, from upper horizon of Object 8 are related to late Bronze age occupation, seen in same excavation area.

\section{Bln-556. Podolie}

$$
\begin{aligned}
& 4455 \pm 80 \\
& 2505 \text { в. } .
\end{aligned}
$$

Charcoal (Quercus sp.) from late Eneolithic settlement in upper Waag valley near Podolie ( $48^{\circ} 40^{\prime} \mathrm{N}$ Lat, $17^{\circ} 47^{\prime} \mathrm{E}$ Long), Trenčín Dist., W Slovakia. Sample from cross section No. 3 from bottom of palisade ditch at $1.10 \mathrm{~m}$ below surface. Archaeol. dated to Bošaca group of the late Channelled Ware. Coll. 1963; subm. by V. Pavúková, Archaeol. Inst. Slovakian Acad. Sci., Nitra. Comment: Bln-556 is 300 to 500 yr older than 
dates of late Channelled Ware in Moravia (Brno-Líšen I, Bln-433: 3925 \pm 150 ), or the corresponding Baden-Kostolac horizon in Yugoslavia (Hissar Bln-351: $4170 \pm$ 120; Pivnica KN-145: $4110 \pm 160$ ).

\section{Bln-482. Postoloprty}

$4925 \pm 80$

2975 B.C.

Charcoal (Quercus sp.) from isolated site in exploitation field of sand quarry Rvenice near Postoloprty (51 $22^{\prime} \mathrm{N}$ Lat, $13^{\circ} 41^{\prime} \mathrm{E}$ Long), Louny Dist. NW Bohemia. Sample from ca. $1.40 \mathrm{~m}$ deep cylinder-shaped pit which at $0.80 \mathrm{~m}$ below surface closed by a burned-loam cover. Pit-filling contained, apart from burned animal bones, ashes, and charcoal remains, a great number of pottery fragments. Since further finds were not observed, the possibility of a cremation burial should not be excluded (Neustupný, 1961). Archaeol. dated to late phase of Baalberg group of Funnel Beaker culture, suggested contemporary with Jevišovice C 2-Siřem type. Coll. 1959 by A. Beneš; subm. by E. Neustupný, Archaeol. Inst. ČSSR Acad. Sci. Prague. Comment: Bln-482 in general agreement with other chronologic evidence, that is with dates of latest Lengyel horizon and early Funnel Beaker culture in N Europe.

\section{Bln-475. Prasklice \\ $3845 \pm 80$}

Carbonized grain (Triticum dicoccum Schrenk, Triticum monococcum L., Triticum aestive-compactum Schiem.) from early Bronze age site on the "Křeby" hill near Prasklice $\left(49^{\circ} 16^{\prime} \mathrm{N}\right.$ Lat, $17^{\circ} 11^{\prime} \mathrm{E}$ Long), Kroměříž Dist., Moravia. Sample from $1.80 \mathrm{~m}$ deep obtuse coned storage pit whose wall and bottom were coated with burned loam. Pit also contains, apart from pottery and a 3 to $4 \mathrm{~cm}$ thick layer of charred grain, 3 burials ( 2 adults, 1 child) on the pit bottom (Ludikovský, 1960). Archaeol. dated to elder phase of Únětic (Aunjetitz) culture. Coll. 1959; subm. by K. Ludikovský, Archaeol. Inst. ČSSR Acad. Sci., Brno. Comment: Bln475 agrees with the relative chronologic position. The late Aunjetitz culture (Leubingen group) in E Germany from Helmsdorf (Bln-248: 3613 $\pm 160)$ and in Great Poland from Leki Male (GrN-5037: $3605 \pm 40)$ has accordingly been dated to a younger age.

\section{Stúrovo series}

Systematic excavations made by the Archaeol. Inst. Slovakian Acad. Sci., Nitra, have since 1965 discovered a large Neolithic settlement on left bank of Danube R. near Stúrovo $\left(47^{\circ} 48^{\prime} \mathrm{N}\right.$ Lat, $18^{\circ} 44^{\prime} \mathrm{E}$ Long), Nové Zámky Dist., SW Slovakia. Site is on a loess terrace $12 \mathrm{~m}$ above Danube level. In subsequent yr ca. $20,000 \mathrm{~m}^{2}$ area with more than 30 houses and numerous other settlement objects from various phases of younger Linear pottery and Zeliezovce group had been investigated (Pavúk, 1967). All samples are taken from clay-burned storage pits which, on the basis of the pottery and the uniform obtuse coned pit profile, are assigned to middle phase of the Želiezovce (Zseliz) type. Coll. 1966; subm. by J. Pavúk. 
Bln-559. Stúrovo-313/66 ject $313 / 66$ ) dug 60 to $70 \mathrm{~cm}$ deep into loess; ca. 1.00 to $1.10 \mathrm{~m}$ below surface.

\section{Bln-558. Stúrovo-229/66}

$6170 \pm 100$

Charcoal (Quercus sp.) from storage pit (Object 229/66) similar by shape, depth, and content.

\section{Bln-557. Stúrovo-215/66}

$5565 \pm 120$

Charcoal (Quercus sp.) from storage pit (Object $215 / 66)$ 3615 B.c. shape, depth, and content.

General Comment: Bln-557 appears too recent in view of archaeologic chronology and compared to date of late Želiezovce phase from Horné Lefantovce (Bln-304: $5775 \pm 140)$.

\section{Hungary}

\section{Bln-607. Aszód-Papi földek}

$5620 \pm 100$

39' Charcoal (Quercus sp.) from Neolithic site at Aszód-Papi földek (47 $39^{\prime}$ N Lat, 19²9' E Long), Aszód Co., Kom. Pest. Sample from settlement Pit XI, depth 1.40 to $1.60 \mathrm{~m}$. Archaeol. date: developed phase of older Lengyel culture. Coll. 1966 by N. Kalicz, Archaeol. Inst., Hungarian Acad. Sci. Budapest; subm. by excavator. Comment: although Bln-607 is somewhat younger than dates of same culture in Austria it seems acceptable in view of archaeol. chronology.

\section{Bln-340. Baracs}

$3735 \pm 80$

and seeds (Lens cf. culinarise 1. polystichum, Triticum monococcum L.) ment at (Lens . Fejér. Sample from lowest stratum on floor of house destroyed by fire, $3.0 \mathrm{~m}$ below surface. Archaeol. date: Nagyrév culture of Hungarian early Bronze age. Coll. 1962 by Archaeol. Dept., Univ. Budapest, in cooperation with Dunaujváros Mus.; subm. by I. Bóna, Archaeol. Dept., Univ. of Budapest. Comment: Bln-340 in general agreement with expected archaeol. age of Nagyrév culture.

\section{Bln-516. Cserépváralja}

$415 \pm 80$

Charcoal (Quercus sp.) from rock shelter in valley of Csordás $\mathbf{R}$. near Cserépváralja (47 $56^{\prime} \mathrm{N}$ Lat, $20^{\circ} 32^{\prime} \mathrm{E}$ Long) Mezökövesd Dist., Kom. Borsod. Sample derived from burnt wooden structure in a square- 
chambered niche, cut in Ryolith rock. Assumed medieval beehive. Coll. 1960, subm. by J. Korek, Hungarian Natl. Mus. Budapest. Comment: date agrees with expected age.

\section{Deszk series}

Rescue excavations by Móra Ferenc Mus., Szeged, uncovered several Neolithic pits on site of oil boring Plant $1 \mathrm{E}$ of Deszk $\left(46^{\circ} 13^{\prime} \mathrm{N}\right.$ Lat, $20^{\circ}$ $15^{\prime}$ E Long), Szeged Dist., Kom. Csongrád. Fragments of biconic vessels of Vinča type, solid pedestalled bowls and frequent Barbotine decoration is typical for a development phase of the Körös culture (Trogmayer, 1968). Coll. 1966; subm. by O. Trogmayer, Móra Ferenc Mus., Szeged.

Bln-582. Deszk-Olajkut No. 1

Bln-582a.

$6390 \pm 100$

Charcoal Sar Average: 4375 B.c.

arcoal Sample 1 (Quercus sp.) from Pit 15 , depth 1.00 to $1.30 \mathrm{~m}$ below surface.

Bln-583. Deszk-Olajkut No. 2

$6410 \pm 120$

Charcoal Sample 2 (Quercus sp.) from Pit 15, depth 2.00 to $2.10 \mathrm{~m}$.

Bln-584. Deszk-Olajkut No. 3

$6540 \pm 100$

Charcoal Sample 3 (Quercus sp.) from Pit 8, depth 1.00 to $1.10 \mathrm{~m}$.

\section{Bln-581. Deszk-Olajkut No. 4}

$6605 \pm 100$

Charcoal Sample 4 (Quercus sp.) from Pit 8, depth 1.00 to $1.60 \mathrm{~m}$. General Comment: Bln-581 to 584 agree with dates for ceramic samples of Hungarian Körös culture at Katalszeg (Bln-86: 6370 1 100) and Hódmezövásárhely-Kotacpart (Bln-115: $6450 \pm 100)$. Late date of Deszk finds indicated by Vinča elements and more frequent use of Barbotine technique is confirmed. The $200 \mathrm{yr}$ difference between Pits 8 and 15 corresponds to differences in archaeol. material and suggests a longer or repeated occupation of the site.

\section{Bln-341. Dunaujváros-Kozider}

$3505 \pm 80$

Polystichum, Hordeum vulgare sticum cf. var. mudum from multi-layered Bronze age settlement at Dunaujváros-Kozider ( $46^{\circ} 58^{\prime} \mathrm{N}$ Lat, $18^{\circ} 56^{\prime} \mathrm{E}$ Long), Dunaujváros Dist., Kom. Fejér. According to information from I. Bóna, archaeol. date to lowest Nagyrév layer is uncertain. It is possible that grain was found in the overlying middle Bronze age laver and only in Dunaujváros museum together with Nagyrév vessel used for exhibition. Coll. 1951 (unknown rescue excavation by Budapest Natl. Mus.); subm. by I. Bóna. Comment: 
Bln-34.1 is much younger than date for Nagyrév culture of Baracs (Bln340: $3735 \pm 80$ ). Sample was probably from level of middle Bronze age (Vatya culture).

\section{Keszthely-Fenékpuszta}

Fenékpuszta site with destroyed remains from various periods of the Hungarian Copper age at $W$ point of Lake Balaton, $6 \mathrm{~km}$ S of Keszthely ( $46^{\circ} 45^{\prime} \mathrm{N}$ Lat, $17^{\circ} 15^{\prime}$ E Long), Keszthely Dist., Kom. Veszprém. Coll. Sept. 1964; subm. by N. Kalisz.

Bln-500. Keszthely-Fenékpuszta No. 1

$$
4780 \pm 80
$$

Charcoal (Quercus sp) from pit (Object 2), ca. $1.50 \mathrm{~m}$ deep, hydrological station. Archaeol. date: Balaton group of $1.50 \mathrm{~m}$ deep, $\mathrm{S}$ of per age.

\section{Bln-501. Keszthely-Fenékpuszta No. 2}

$4890 \pm 80$ factory $S$ of Lower part of pit was influenced by ground water. Archaeol. der Bln-500, besides fragments similar to Gajáry type. Comment: Bln-500 and probably 501 date Transdanubian features of Hungarian Copper age, established by N. Kalisz as so-called Balaton group, genetically related to contemporary Bodrogkeresztur culture.

\section{BIn-609. Kétegyháza}

$4265 \pm 80$

Charcoal (Quercus sp.) from burial place at Törökhálom near Kétegyháza (46 $36^{\circ} \mathrm{N}$ Lat, $21^{\circ} 11^{\prime} \mathrm{E}$ Long), Gyula Dist., Kom. Bekes. Sample from timber beam construction of Grave 4 found in center of $7 \mathrm{~m}$ high mound; on the floor of grave pit was a W-E oriented contracted skeleton with ochre traces and perforated animal teeth. The burial mound, at the base nearly $70 \mathrm{~m}$ diam., was erected above a settlement of the Bodrogkeresztur culture. Archaeol. assignment to so-called Ochergrave culture, a variant of the South Russian Pit-grave culture. Coll. 1967; subm. by B. Gazdapusztai, Inst. of Archaeol. and Ancient History, Univ. Szeged. Comment: BIn-609 appears somewhat older than Ochergrave dates from Baja-Hamangia in Rumanian Moldavia (Bln-29: 4090 $\pm 160 ; \mathrm{KN}-38: 4060 \pm 160)$ and corresponds roughly to earliest Pit-grave horizon at Michailovka I (Bln-630: $4330 \pm 100)$ and dates from same culture in N Caucasian region (Tsatsa UCLA-1270: $4210 \pm 80$, Ust-man UCLA-1271: $4150 \pm 80$ ).

\section{Kisköre}

During excavations 1964 to 1966, the Budapest Natl. Mus. discovered at $1200 \mathrm{~m}^{2}$ area of Neolithic settlement and 36 burials of the Tisza cul- 
ture near Kisköre-Gat ( $47^{\circ} 30^{\prime} \mathrm{N}$ Lat, $20^{\circ} 30^{\prime}$ E Long), Heves Dist., Kom. Heves. Coll. 1965; subm. by J. Korek, Hungarian Natl. Mus., Budapest.

\section{Bln-515. Kisköre-Gat No. 1}

$5890 \pm 120$

Charcoal (Quercus sp.) from fireplace in pit (XVII,6) $1.60 \mathrm{~m}$ deep. Archaeol. date: younger phase of Tisza culture corresponding to finds of Lebö-Alsóhalom and Gorsza.

\section{Bln-179. Kisköre-Gat No. 2}

$5995 \pm 80$

Sherds of thick-walled, organic-tempered ceramics, from same pit at 0.80 to $1.60 \mathrm{~m}$ below surface. Archaeol. date as under Bln-515. Comment: both dates, though based upon different material, are in fairly good agreement. Comparison with I.engyel dates from Trans-Danubia and Austria verifies assumed parallel development of early Lengyel culture with younger Tisza-groups in E Hungary.

\section{Bln-585. Letenye-Szentkeresztdomb}

$\mathbf{5 4 6 0} \pm \mathbf{1 2 0}$

3510 B.c.

Charcoal (Quercus sp.) from site at Szentkeresztdomb hill near Letenye $\left(46^{\circ} 26^{\prime} \mathrm{N}\right.$ Lat, $16^{\circ} 43^{\prime}$ E Long), Letenye Dist., Kom. Zala. Sample from rescue excavation at 0.60 to $0.90 \mathrm{~m}$ below surface in Pit 19 . Archaeol. date: late phase of Lengyel culture (with white painting). Coll. Aug. 1965; subm. by N. Kalisz. Comment: compared with dates of early Lengyel culture from Austria (Langenzersdorf, Oberpullendorf) Bln-585 corresponds to expected younger radiocarbon age and is in good agreement with equally late Lengyel finds from Zalavar-Mekenye (Bln-502: $5400 \pm 80)$.

\section{Bln-508. Neszmély-Tekerspatak}

$5435 \pm 100$

3485 B.C.

Charcoal (Quercus sp.) from Neolithic site on S banks of Danube R. near Neszmély-Tekerespatak (47 $43^{\prime} \mathrm{N}$ Lat, $18^{\circ} 23^{\prime} \mathrm{E}$ Long), Tata Dist. Kom. Komárom. Sample was $0.80 \mathrm{~m}$ below surface from cylinder-shaped storage pit (grain silo) dug into loess soil. Archaeol. date: early phase of Zseliz type of Linear pottery (Bandkeramik). Coll. 1959 by J. Makkay; subm. by Archaeol. Inst., Hungarian Acad. Sci., Budapest. Comment: Bln508 appears too recent in view of relative chronology and does not agree with other dates of the Zseliz (Želiezovce) group in SW Slowakia from Štúrovo (cf. Bln-557 to 559) and Horné Lefantovce (cf. Bln-304). Contamination might have occurred by roots observed at the site down to $0.80 \mathrm{~m}$ below surface.

\section{Bln-549. Ostoros}

$6180 \pm 100$

4230 B..

Sherds of organic-tempered ceramic from Neolithic site near Ostoros village ( $47^{\circ} 52^{\prime} \mathrm{N}$ Lat, $20^{\circ} 26^{\prime}$ E Long), Eger Dist., Kom. Heves. Assumed 
archaeol. assignment, on basis of atypical surface finds and some Macrolithic flint artifacts to an early stage of $\mathrm{N}$ Hungarian Neolithic. Coll. 1966; subm. by L. Vertes, Hungarian Natl. Mus., Budapest. Comment: Bln-549 establishes location in time of site which could not be dated otherwise. Connection of finds with younger Alföld linear pottery or Bükk culture of similar age appears more likely.

\section{Oszentiván VIII-series}

Ószentiván site is situated on small hill in the Tisza-Maros corner $\mathrm{SW}$ of present village Tiszasziget $\left(46^{\circ} 12^{\prime} \mathrm{N}\right.$ Lat, $20^{\circ} 11^{\prime} \mathrm{E}$ Long), Szeged Dist., Kom. Csongrád. Samples were taken during rescue excavations of Budapest Natl. Mus. at Site VIII from pits of Baden culture (Pit I a) and Neolithic Banát group (Pit VIII/e). Coll. 1960; subm. by I. BognárKutzián, Archaeol. Inst., Hungarian Acad. Sci., Budapest.

\section{Bln-476. Oszentiván VIII No. 1}

$4515 \pm 80$ 2565 B.c.

Charcoal (Ulmus sp.) from Pit $\mathrm{I} / \mathrm{a}, 1.40$ to $1.70 \mathrm{~m}$ below surface. Archaeol. dated to Baden-Pécel culture with Kostolac elements.

\section{Bln-479. Oszentiván VIII No. 2}

$6460 \pm 80$

Charcoal (Quercus sp.) from Pit VIII/e 2, 0.65 to $0.90 \mathrm{~m}$ below surface. Archaeol. dated to so-called Banát group, a variant of the early Vinča culture in SE Hungary (Banner and Párducz, 1948).

\section{Bln-480. Oszentiván VIII No. 3}

$6050 \pm 100$

Charcoal (Quercus sp.) from Pit VIII/e 3, 0.75 to $1.00 \mathrm{~m}$ below surface. Archaeol. dated as Bln-479.

\section{Bln-477. Oszentiván VIII No. 4 \\ $6270 \pm 80$}

Charcoal (Ulmus sp.) from Pit VIII/e 4, 1.00 to 1.20 m below surface. Archaeol. dated as Bln-479.

\section{Bln-478. Oszentiván VIII No. 5}

$6070 \pm 100$

Charcoal (Quercus sp.) from Pit VIII/e 5, 1.20 to $1.50 \mathrm{~m}$ below surface. Archaeol. dated as Bln-479.

General Comment: Bln-476 appears considerably older than dates of Baden-Kostolac similar finds from Hissar IIa (Bln-351: 4170 \pm 120) and Kostolac settlement at Pivnica in N Bosnia (KN-145: $4110 \pm 160)$. Although Samples Bln-477 to 480 of Neolithic Banát group originate from same pit, $\mathrm{C}^{14}$ values differ remarkably. Result of Bln-478 and 480 appear too recent in view of relative chronologic system. 


\section{Tarnazsadány-Sándorrésze}

Site repeatedly occupied from Neolithic to early Bronze age is in riverside area near Tarnazsadány-Sándorrésze $\left(47^{\circ} 39^{\prime} \mathrm{N}\right.$ Lat, $20^{\circ} 9^{\prime} \mathrm{E}$ Long), Heves Dist., Kom. Heves. During rescue diggings necessitated by river improvement work, 3 settlement objects were investigated. Archaeol. assignment of finds to Szakálhát group of younger Linear pottery in SE Hungary. Coll. 1963; subm. by N. Kalicz.

\section{Bln-506. Tarnazsadány-Sándorrésze No. 1 \\ $6120 \pm 100$}

Charcoal (Quercus sp. from lower part of Pit 1, $1.60 \mathrm{~m}$ below surface.

\section{Bln-676. Tarnazsadány-Sándorrésze No. 2}

$6155 \pm 80$

Sherds of organic-tempered pottery from same Pit 1. Comment: Bln506 and 676 are, despite different sample material, nearly identical. They confirm younger dates of Szákalhát group and its parallel development with Zseliz-Želiezovce type (cf. Stúrovo Bln-558-559) in W Karpathian basin.

\section{Tiszapolgár-Csöszhalom series}

Excavation by Budapest Natl. Mus. in well-known Eneolithic settlement at Csöszhalom near Tiszapolgár (47 $52^{\prime} \mathrm{N}$ Lat, $21^{\circ} 7^{\prime} \mathrm{E}$ Long), Polgár Dist., Kom. Hajdu-Bihar. Site is a Tell settlement with $3.50 \mathrm{~m}$ thick cultural layer which can be divided in 6 successive levels (A-F). Archaeol. assignment of all samples to Csöszhalom group (named after discovery site), a local group of Eneolithic painted pottery province in $\mathrm{E}$ Hungarian lowlands. Coll. 1957; subm. by I. Bognár-Kutzián.

\section{Bln-509. Tiszapolgár-Csöszhalom No. 1}

Charcoal Sample 1 (Quercus sp.) from House I/A in uppermost level, 0.30 to $0.40 \mathrm{~m}$ below surface.

Bln-510. Tiszapolgár-Csöszhalom No. 2

Charcoal Sample 2 (Quercus sp.) from cultural layer in Sec. I/10, $1.85 \mathrm{~m}$ below surface.

Bln-512. Tiszapolgár-Csöszhalom No. 3

3825 B.c.

Charcoal Sample 3 (Quercus sp.) from floor of fire-destroyed house (I/F 16 a) in lowest level, 3.05 below surface.

\section{Bln-513. Tiszapolgár-Csöszhalom No. 4}

Charcoal Sample 4 (Quercus sp.) from lowest level of House $\mathrm{I} / \mathrm{F}$, 3.10 to $3.30 \mathrm{~m}$ below surface. 
General Comment: with exception of Bln-510, date sequence of Csöszhalom series agrees with stratigraphic order. Bln-512 and 513 for lowest Level F further indicate agreement with earlier Groningen data of same complex (GrN-1943: $5845 \pm 60)$.

\section{Bln-505. Tiszavasvári-Keresztfal}

Charcoal (Ulmus carpinifolia Gled.) from Neolithic settlement in Tiszavasvári-Keresztfal (47 $58^{\prime} \mathrm{N}$ Lat, $21^{\circ} 23^{\prime} \mathrm{E}$ Long), Tiszalök Dist., Kom. Szabolcs-Szatmár in NE Hungary. Sample from $8 \times 3 \mathrm{~m}$ large pit (Object III) at 1.60 to $1.80 \mathrm{~m}$ below surface. Archaeol. date: developed phase of E Hungarian Alföld linear pottery. Coll. 1963; subm. by N. Kalicz. Comment: Bln-505 corresponds to earlier date of Alföld-Bandkeramik of Tarnabod (Bln-123: $6280 \pm 100)$ and is somewhat older than same finds with some painted pottery from Szamossály (B1n-404: 6136 $\pm 100)$.

\section{Bln-502. Zalavár-Mekenye \\ $5400 \pm 80$}

Charcoal (Abies cf alba Mill) from Mekenye site, occupied in late Neolithic and Copper age, $1.5 \mathrm{~km} \mathrm{~S}$ of Zalavár $\left(46^{\circ} 40^{\prime} \mathrm{N} \mathrm{Lat,} 17^{\circ} 10^{\prime} \mathrm{F}\right.$ Long), Keszthely Dist., Kom. Veszprém. Sample from lower part of Pit 13, ca. $1 \mathrm{~m}$ below surface. Archaeol. dated to late phase of Lengyel culture, marked by white painting and high proportion of undecorated pottery. Coll. Sept. 1964; subm. by N. Kalicz. Comment: Bln-502 agrees with late Lengyel date from Letenye-Szentkkeresztdomb (Bln-585: $5460 \pm 120$ ). There is further agreement of dates from periphery groups of late Lengyel horizon in W Central Europe, such as Aichbühl (Lautereck GrN4666: $5430 \pm 40$ ) and Gatersleben (Kmehlen Bln-231: $5360 \pm 160$ ).

\section{Soviet Union}

\section{Bln-631. Čapaevka}

Charcoal (Fraxinus sp.) from late Tripolye site at C̆apaevka $\left(50^{\circ} 26^{\prime}\right.$ $\mathrm{N}$ Lat, $30^{\circ} 30^{\prime} \mathrm{E}$ Long), Kiev-Svjatošinskij Rayon, Kiev Dist. Samples from different pits $(1 / 66,6 / 66,12 / 66,16 / 66)$; average depth in loess is 0.40 to $1.00 \mathrm{~m}$ below surface. Archaeol. date: late Tripolye culture, $\mathrm{C}_{\mathrm{I}}$ period (T. S. Passek system), or Cucuteni B (Rumanian research), respectively. Coll. 1966; subm. by V. Kruc, Archaeol. Inst., Acad. Sci., Ukrainian SSR, Kiev. Comment: Bln-631 acceptable in view of relative Tripolye chronology; general agreement with date of the late Cucuteni B settlement Valea-Lupului in Rumanian Moldavia (GrN-1982: $4950 \pm$ $60)$.

\section{Bln-629. Majaki}

$4400 \pm 100$

Charcoal (Ulmus sp.) from Late Neolithic/Early Bronze age settlement at $\mathrm{R}$. Dniestr mouth near village Majaki $\left(46^{\circ} 10^{\prime} \mathrm{N}\right.$ Lat, $30^{\circ} 8^{\prime} \mathrm{E}$ 
Long), Beljaevka Rayon, Odessa Dist. Sample from depth $2.8 \mathrm{~m}$ from trench made to defend settlement. Archaeol. date: Usatovo group, a local variant of latest Tripolye culture influenced by $E$ steppe cultures (Zbenovič, 1968). Coll. 1964; subm. by V. G. Zbenovič, Archaeol. Inst., Acad. Sci., Ukrainian SSR, Kiev. Comment: although Bln-629 agrees with an earlier date for the same site (LE-645: $4340 \pm 65$ ), a difference of 500 yr remains between late Tripolye $C_{1} /$ Cucuteni $B$ settlements of Capaevka (Bln-631: $4870 \pm$ 100) and Valea Lupului (GrN-1982: $4950 \pm 60$ ), with no apparent explanation.

\section{Bln-630. Michailovka I}

$4330 \pm 100$ $\mathbf{2 3 8 0 ~ B . C . ~}$

Charred reed (Phragmites communis Trin) from a multi-layered settlement at Michailovka ( $47^{\circ} 30^{\prime} \mathrm{N}$ Lat, $33^{\circ} 55^{\prime} \mathrm{E}$ Long), Rayon Novo Voronzovka, Cherson Dist. Site I is on a terraced plateau of R. Podpol'na (a right tributary to Dniepr) was occupied during transition from Late Neolithic to Early Bronze age (Lagodovskaja et al., 1962). Sample from the burnt roof cover of a $17 \times 5 \mathrm{~m}$ hut (Zemljanka I) of the lowest cultural layer; depth 1.50 to $2.00 \mathrm{~m}$. Archaeol. date in an early (Pre-Jamna) phase of the Pit-grave culture. Coll. 1952 by E. F. Lagodovskaya et al.; subm. by O. G. Šapošnikova, Archaeol. Inst., Acad. Sci. Ukrainian SSR, Kiev. Comment: Bln-630 is in general agreement with other dates of the Pit-grave culture; corresponds approx. to Usatovo type of Majaki (Bln629: 4400 土 100; LE-645: $4340 \pm 65$ ).

\section{Rostov-series}

Samples from burial place of Early Bronze age in neighborhood of

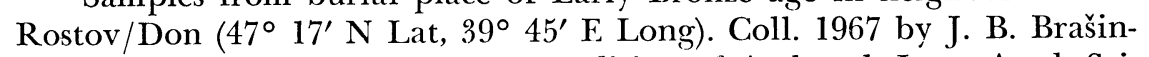
ski and A. I. Demčenko, S Don Expedition of Archaeol. Inst., Acad. Sci. USSR, Leningrad. Subm. by P. M. Doluchanov.

\section{Bln-693. Rostov Kurgan V/6}

Rotten wood (Crataegus sp.) from floor of entrance into secondary Grave 6 of Barrow V. Archaeol. dated to N Caucasian Catacomb Grave culture.

\section{Bln-694. Rostov Kurgan VI/12}

$4215 \pm 100$

Charcoal (Ulmus sp.) and carbonized remains from vessel in Grave 12 of Barrow VI. Archaeol. dated to Don variant of Catacomb Grave culture.

Bln-696. Rostov Kurgan I/5

$4005 \pm 100$

Rotten wood (cf. Aesculus hippocastanus) from floor of entrance into Grave 5 of Barrow I. Archaeol. dated as Bln-694. 


\section{Bln-697. Rostov Kurgan VI/11}

$4065 \pm 120$

Rotten wood (Ulmus sp.) from floor of entrance into Graves 11/12 of Barrow VI. Archaeol. dated as Bln-694.

General Comment: Bln-694 is somewhat older than expected. Other dates in good agreement with LE-624: $3880 \pm 90$ from Rostov Kurgan VII/ 3 and a Catacomb Grave date from Kuban area in Kudinov (UCLA1273: $3860 \pm 80$ ).

\section{Bln-590. Novye-Rusešty I}

$5565 \pm 100$

Charcoal (Fraxinus sp.) fror 3-layered Neolithic settlement near Novye-Rusešty ( $46^{\circ} 53^{\prime} \mathrm{N}$ Lat, $28^{\circ} 45^{\prime} \mathrm{E}$ Long), Rayon Kotovsk, Moldavian SSR. Site I, on lower terrace of R. Botna, was already occupied during time of Linear pottery, following in stratigraphic order, a late phase of Tripolye A period and above it a layer with finds of the Tripolye $B_{I}$ (after T. S. Passek system). Sample from 1.20 to $1.50 \mathrm{~m}$ below surface of Zemljanka 2. Archaeol. date: end of Tripolye A (Pre-Cucuteni) with elements as a transition to Tripolye $\mathrm{B}_{\mathrm{I}}$ (Cucuteni A). Coll. 1964; subm. by V. I. Markevič, Archaeol. Dept., Inst. of Hist., Acad. Sci. Moldavian SSR, Kišinev. Comment: BIn-590 is in general agreement with other chronologic evidence; fits well with dates of early phase of Gumelnita culture (cf. Bln series from Cascioarele) and the younger Cucuteni $\mathrm{A}_{3}$ settlement in Habasesti (GrN-1985: $5330 \pm 80)$.

\section{Soroki series}

Samples from 2 neighboring early Neolithic sites on the right Dniestr bank, a few $\mathrm{km}$ downstream of Soroki $\left(48^{\circ} 11^{\prime} \mathrm{N}\right.$ Lat, $28^{\circ} 19^{\prime} \mathrm{E}$ Long), Rayon Soroki, N of Moldavian SSR. During the open field work carried out by the Moldavian Archaeol. expedition, V. I. Markevič discovered a number of multi-layered settlements in Middle-Dniestr-region, which necessitated study of the origin of the Neolithic in NW Black Sea region. This mainly applies to the stratigraphic evidence of aceramic (post-Mesolithic) layers, in which the beginning neolithization is recognized in the osteologic material (pig domestication). Neolithic development starting from the proto-Neolithic phase in the 2nd half of the 6th millennium, can be followed up via 4 successive phase of the BugDniestr-culture (earlier called Southern Bug culture) up to the beginning Tripolye period at the end of the 5th millennium (Markevič, 1965 and 1969). All samples coll. 1964 to 1966, and subm. by V. I. Markevič, Acad. Sci. Moldavian SSR, Kišinev.

\section{Bln-588. Soroki-Trifauckij les $2 /$ III}

$7515 \pm 120$

5565 в.c.

( $R$. of R. Dniestr $2.5 \mathrm{~km}$ downstream from Soroki. The 3 Neolithic layers between 3.3 and $4.7 \mathrm{~m}$ depth, are separated by ca. $25 \mathrm{~cm}$ thick inter- 
mediate layers of sandy loam, overlain by $3 \mathrm{~m}$ thick fluviatile sediments. Sample was taken 1964 from pit within lowest Layer III; depth 4.6 to $4.7 \mathrm{~m}$ below surface. Archaeol. date: post-Mesolithic or aceramic phase of early Neolithic, respectively.

Bln-587. Soroki-Trifauckij les $2 /$ II

$7420 \pm 80$

Charcoal (Ulmus sp.) from same settlement and with same data as Bln-588. Coll. 1965 from pit within middle Layer II; depth 3.8 to $4.1 \mathrm{~m}$. Archaeol. date: same as Bln-588.

\section{Bln-586. Soroki-Trifauckij les $2 /$ I}

$6825 \pm 150$

Charcoal (Fraxinus sp.) from same settlement and with same data as Bln-588. Coll. 1964 from pit within upper Layer I; depth 3.3 to $3.5 \mathrm{~m}$. Archaeol. date based on ceramic finds: Sokolecka phase of Bug-Dniestr culture.

\section{Bln-589. Soroki-Trifauckij les 5}

$6495 \pm 100$

Charcoal (Fraxinus sp.) from mono-layered settlement; geog. position same as Soroki 2 site, $500 \mathrm{~m}$ apart. Coll. 1966 from fireplace at $2 \mathrm{~m}$ depth. Above cultural layer is $1.5 \mathrm{~m}$ thick sterile loam, turning upwards into humic forest soil. Archaeol. date: Savran phase of the late Bug-Dniestr culture.

General Comment: Samples Bln-586 to 588 from Soroki-Trifauckij les 2 site agree with stratigraphic position. The aceramic proto-Neolithic layers are of older radiocarbon age than the early Neolithic of the Starčevo/Körös/Karanovo I type. This, in connection with the other archaeol. finds in the N Black Sea and Azov region, suggests a level of incipient domestication and cultivation largely independent of SE Europe, which might possibly have been influenced from the AraloCaspian area. Dates for 2nd (Sokolecka) and 5th (Savran) phase of the Bug-Dniestr culture (Bln-588 and 589) likewise correspond to the relative chronology. Relation to the neighboring Körös (Cris) culture in Rumainian Moldavia-indicated in the ceramics of the Sokolecka phase-are confirmed by comparison with early Neolithic Bln-dates from Hungary and Yugoslavia.

\section{Bln-712. Murat-Uzun Kul'}

A.D. 1330

$620 \pm 100$

Charcoal from the Mesolithic-Neolithic site Murat on the banks of Lake Uzun Kul', S Ural (5352' N Lat, $58^{\circ} 44^{\prime}$ E Long) Rayon Belorezk, Bashkir ASSR. Site, sounded first in 1963, is a multi-layered settlement whose oldest phase with microlithic tools might be dated back to the Mesolithic. Overlying a number of horizons with chiefly Comb and Pitmarked Pottery indicate cultural development in S Ural region in Neo- 
lithic and Eneolithic times (Matjušin, 1965). Sample was in Sonde 3/66 (Area V3-G3) taken from the upper level at 0.29 to $0.39 \mathrm{~m}$ immediately below upper surface humus. Archaeol. date: S Ural-Eneolithic period. Coll. 1966 and subm. by G. N. Matjušin, Archaeol. Inst., Acad. Sci. USSR, Moscow. Comment: Bln-712 does not agree with expected archaeol. age in 3rd millennium. If sample cannot be related to a later medieval settlement of the site, a secondary contamination must be assumed owing to its position near the surface.

\section{Bln-713. Davlekanovo}

$1375 \pm 100$

Charcoal from multi-layered Neolithic site at Davlekanovo $\left(54^{\circ} 10^{\prime}\right.$ $\mathrm{N}$ Lat, $55^{\circ} 6^{\prime} \mathrm{E}$ Long), ca. $80 \mathrm{~km} \mathrm{SW}$ Ufa, Bashkir ASSR. Sample consisted of charcoal fragments from a layer near surface. Expected archaeol. date: Belaja-Kama group of Comb and Pit-marked Pottery complex. Coll. 1967 and subm. by G. N. Matjušin. Comment: see Bln-712.

\section{Bln-769. Sarnate}

$4640 \pm 100$

Peat from Neolithic bog settlement near Sarnate $\left(57^{\circ} 8^{\prime} \mathrm{N}\right.$ Lat, $21^{\circ}$ $26^{\prime}$ E Long) Ventspils Ray., Latvian SSR. Sample from Holocene peat layer containing cultural remains in depth 0.60 to $0.70 \mathrm{~m}$ below surface. Archaeol. date to Comb and Pit-marked Pottery complex. Coll. 1968 by P. M. Doluchanov and L. V. Vankina, Historical Mus. Riga. Subm. by P. M. Doluchanov, Archaeol. Inst. Leningrad. Comment: Bln-769 agrees with dates of the same cultural layer (TA-24: $4490 \pm 250$, TA-26: 4700 \pm 250, LE-814: $4510 \pm 110$ ).

\section{Altyn-Depe series}

The settlement mound Altyn-Depe ( $36^{\circ} 53^{\prime} \mathrm{N}$ Lat, $60^{\circ} 26^{\prime} \mathrm{E}$ Long), systematically investigated since 1965 , is at $\mathrm{N}$ margin of the Kopet-Dag Mts. near Meana in S of Turkmenian SSR. Previous excavations on the ca. 110 acre and $20 \mathrm{~m}$ high tell settlement covered upper layers of middle (Namazga V) and early Bronze period (Namazga IV) at center of mound as deep as 12 to $14 \mathrm{~m}$. Buildings of an old monumental architecture influenced by Mesopotamia were discovered for the first time in 1967, indicating that the Altyn-Depe was a large urbanized center (Masson, 1967 and 1968). Archaeol. date: Namazga V period (Anau III culture). Coll. 1967 and subm. by V. I. Sarianidi, Archaeol. Inst., Acad. Sci. USSR, Moscow.

\section{Bln-716. Altyn-Depe No. 1}

Charcoal sample from Sonde 7/67, from front of the $6.5 \mathrm{~m}$ high tower platform built by air-dried bricks, ca. $1.5 \mathrm{~m}$ below surface. 
Bln-717. Altyn-Depe No. 2

Charcoal from Sonde 7/67, from fireplace in Building 3, ca. $0.60 \mathrm{~m}$ below surface.

General Comment: Bln-716 and 717 are about same radiocarbon age, as are dates of the late Namazga IV type from Altyn-Depe Level 4 (LE-664: $4070 \pm 50$ ) and Ulug-Depe (cf. Bln-714 and 715).

\section{Bln-720. Geoksjur 1}

Charcoal (Saliceen wood) from an Eneolithic settlement in Geoksjur oasis (37 $24^{\prime} \mathrm{N}$ Lat, $60^{\circ} 46^{\prime} \mathrm{E}$ Long) at SE margin of the Karakum, $20 \mathrm{~km}$ to the $\mathrm{E}$ of Tedžen in S Turkmenian SSR. Geoksjur 1 site, for the first time investigated by the S Turkmenian Archaeol. Expedition in 1956, belongs to a group of 9 settlement mounds. In $10 \mathrm{~m}$ high Mound 1 a continuous occupation was found from the late Namazga I to the early Namazga III period. The sample was in the central part of the Tell on the floor of a building made of air-dried bricks (No. 54) ca. $1 \mathrm{~m}$ below surface (Chlopin, 1964; Sarianidi, 1965). Archaeol. date: Namazga III period. Coll. 1964; subm. by V. I. Sarianidi, Archaeol. Inst., Acad. Sci. USSR, Moscow. Comment: Bln-720 appears somewhat older than Leningrad date of the same Building 54 (LE-647: $4440 \pm 180$ ) and agrees with date of Namazga III period of Kara-Depe (RUL-2: $4700 \pm 120$ ). The horizon Namazga III-Hissar IB/C-Sialk III/4-7-Late Uruk indicated by archaeol. connections across central Iranian plateau, however, suggests it is probably 400 to 600 yr older.

\section{Togolok-Depe series}

Neolithic mound Togolok-Depe (38 $8^{\circ} 7^{\prime} \mathrm{N}$ Lat, $57^{\circ} 57^{\prime} \mathrm{E}$ Long) at $\mathrm{S}$ margin of the Karakum near Geok-Tepe R. R. Sta., ca. $45 \mathrm{~km} \mathrm{NW}$ of Ašchabad in Turkmenian SSR. Investigation started 1967 covers 3 subsequent layers with painted Neolithic ceramics. Also discovered were several small houses with domestic rooms surrounding them. Samples were taken from cultural layers within the settlement (Berdyev, 1968). Archaeol. date: Jeitun culture, a Neolithic period preceding Anau I A and Namazga I (Anau I B). Coll. 1967; subm. by V. Sarianidi.

Bln-718. Togolok-Depe No. 1

$6890 \pm 100$

Charcoal samples from Level 2, ca. $0.5 \mathrm{~m}$ below surface.

Bln-719. Togolok-Depe No. 2

$7320 \pm 100$

5370 B.c.

Charcoal sample from Level 3, ca. $0.8 \mathrm{~m}$ below surface. Comment: Bln-718 and 719 correspond to stratigraphic sequence and confirm antiquity of the Central Asian Neolithic. The Anau IA period, following 
Jeitun culture, from Čagylly-Depe (Meana-Čača Rayon) indicates a radiocarbon age of $7000 \pm 100$ B.P. (LE-592).

\section{Ulug-Depe series}

Ulug-Depe mound $\left(37^{\circ} 10^{\prime} \mathrm{N}\right.$ Lat, $60^{\circ} 5^{\prime} \mathrm{E}$ Long), occupied from the Eneolithic up to Achamendic period is in lower lands of Kopet-Dag Mts. near Dušak R. R. Sta., ca. $180 \mathrm{~km}$ SE of Ašchabad, in S Turkmenian SSR. The settlement mound investigated in 1967 covers ca. 25 acre area and $30.5 \mathrm{~m}$ height. Soundings at 3 places in upper parts of Tell indicate 3 Bronze age levels with buildings and by potter's wheel made ceramic of Namazga V (upper level Ulug-Depe 1) and Namazga IV type (Ulug-Depe 2 and 3) (Sarianidi, 1968). Archaeol. date: Namazga IV period (corresponds to early Anau III culture). Coll. 1967; subm. by V. I. Sarianidi.

\section{Bln-714. Ulug-Depe Level 2}

$4095 \pm 100$

Charcoal (Ulmaceen wood) from Sonde 1, from Level 2, $1.5 \mathrm{~m}$ below surface.

\section{Bln-715. Ulug-Depe Level 3}

$4140 \pm 100$

Charcoal (Juglandaceen wood) from Sonde 1, from Level $3,2.00 \mathrm{~m}$ below surface. Comment: Bln-714 and 715 are consistent and comparable with date of late Namazga IV period from Altyn-Depe Level 4 (LE-664: $4070 \pm 50$ ).

\section{Bln-698. Woznesenovka}

$5115 \pm 160$

Charcoal from multi-layered Neolithic settlement near mouth of Chungari R. to Amur at hill site Stary Stanok N of Woznesenovka $\left(50^{\circ}\right.$ $4^{\prime}$ N Lat, $136^{\circ} 54^{\prime}$ E Long), Rayon Komsomol'sk, Chabarovsk Dist. Sample from loamy layer with early Neolithic ceramic (red-burnished and comb-decorated pottery), overlain by fluviatile sediments; depth 2.00 to $2.25 \mathrm{~m}$ below terrace surface. Expected age 3/4 millennium B.c. (Okladnikov, 1967). Coll. 1966 by Far Eastern Archaeol. Expedition, dir. by A. P. Okladnikov, Siberian Dept. Acad. Sci. USSR, Novosibirsk. Subm. by excavator.

\section{Bln-699. Malyševo-na-Amure}

$3875 \pm 120$

Charcoal from Neolithic site on right bank of Amur R. downstream Chabarovsk near village Malyševo-na-Amure $\left(48^{\circ} 45^{\prime} \mathrm{N}\right.$ Lat, $135^{\circ} 40^{\prime} \mathrm{E}$ Long), Dist. Chabarovsk. Sample $2.10 \mathrm{~m}$ below surface from cultural layer in 3rd terrace of R. Amur. Expected age 2/3 millennium в.c. Coll. and subm. as Bln-698. Comment: Bln-699 is somewhat older than date from same site in Leningrad Lab. (LE-663: $3590 \pm 60$ ). 


\section{REFERENCES}

Bánesz, L., 1959, Neolitické pece z Hornych Lefantoviec: Archeol. rozhledy, v. 11, p. $470-482$.

Banner, J. and Parducz, M., 1948, Contributions nouvelles à l'histoire du néolithique en Hongrie: Archaeol. Ertesitö, 1946-48, p. 30-41.

Berdyev, O., 1968, Izucenie pamjatnikov epochi neolita juznogo Turkmenistana: Archeol. otkrytija 1967 goda, Moskva, p. 341-342.

Chlopin, I. N., 1964, Geoksjurskaja gruppa poselenij epochi eneolita, Moskva.

Gramsch, B., 1966, Neue Ausgrabungen auf dem spätmesolithischen Siedlungsplatz "Buddelin" bei Lietzow, Kr.Rügen: Ausgrabungen und Funde, v. 11, p. 179-183. 1969, Die Lietzow-Kultur Rügens und ihre Bezichung zur Ostseegeschichte: Petermanns Geog. Mitt., v. 113, in press.

Hollnagel, A., 1967, Die Großsteingräber von Frauenmark, Kreis Rostock: Bodendenkmalpflege in Mecklenburg, Jahrb. 1966 (1967), p. 183-200.

Kaufmann, D., 1969, Zwei Gräber der Glockenbecherkultur mit Holzeinbauten von Löbnitz, Kr. Stassfurt: Ausgrabungen und Funde, v. 14, p. 27-31.

Kohl, G. and Müller, H., 1969, Berlin radiocarbon measurements III: Radiocarbon, v. 11, p. 271-277.

Kohl, G. and Quitta, H., 1964, Berlin radiocarbon measurements I: Radiocarbon, v. 6, p. $308-317$

1966, Berlin radiocarbon measurements II: Radiocarbon, v. 8, p. 27-45.

Kruta, V. et al., 1966, Village néolithique a Chabarovice près de Usti nad Labem (Bohême): Inv. Archéol. en Tchécoslovaquie, p. 60-62.

Lagodovskaja, O. F., Sapošnikova, O. G., and Makarevic, M. L., 1962, Michajlivs'ke poselennja, Kiiv.

Ludikovsky, K., 1960, Unětická obilní jáma s hromadnym pohrbem v Prasklicich: Prehled vyzkumu, 1959, p. 41.

Markevic, V. I., 1965, Issledovanija neolita na Srednem Dnestre: KSIA AN, v. 105 p. $85-90$. Moldavii, Kišinev, p. 3-34.

Masson, V. M., 1967, Protogorodskaja civilizacija juga Srednej Azii: Sovetskaja archeol., v. 3 , p. $165-190$

1968, The urban revolution in southern Turkmenia: Antiquity, v. 42, no 167 , p. $178-186$.

Matjušin, G. N., 1965, Stojanka Murat na ozere Uzun-Kul': Sovetskaja archeol., v. 1, p. $135-153$.

Medunová-Benešová, A., 1964, Eneolitické vyšinné sidliště Staré Zámky v Brně-Líšni: Památky archeol., v. 55, p. 91-155.

Neustupny, E. F., 1961, Nález kultury nálevkovitych poháru z Postoloprt, okr. Zatec: Památky archeol., v. 52, p. 100-104.

Okladnikov, A. P., 1967, Poselenie u s. Woznesenovka vblizi ust'ja r. Chungari: Archeol. otkrytija 1966 goda, Moskva, p. 175-179.

Pavúk, J., 1967, Vyskum neolitického sídliska v Stúrove: Archeol. rozhledy, v. 19, p. 576583 .

Peschel, K., 1963, Ein Grabhügel mit Schnurkeramik von Dornburg, Landkreis Jena: Praehist. Zeitschr., v. 41, p. 83-133.

Quitta, H., 1958, Die Ausgrabungen in der bandkeramischen Siedlung Zwenkau-Harth, Kr. Leipzig: Neue Ausgrabungen in Deutschland, Berlin.

Sarianidi, V. I., 1965, Pamjatniki pozdnego eneolita jugo-vostocnoj Turkmenii: Archeol. SSSR B 3-8, v. 4, Moskva, p. 7-13.

Sarianidi, V. I. and Kacuris, K. A., 1968, Raskopki na Ulug-Depe: Archeol. otkrytija, 1967 goda, Moskva, p. 342-345.

Schuldt, E., 1967, Die Ganggräber von Liepen, Kreis Rostock: Bodendenkmalpflege in Mecklenburg, Jahrb. 1966 (1967), p. 70-112.

Schuldt, E. and Wetzel, G., 1967, Die Ganggräber von Gnewitz, Kreis Rostock: Bodendenkmalpflege in Mecklenburg, Jahrb. 1966 (1967), p. 113-182.

Tichy, R., 1966, Village fortifié néolithique a Krepice près de Znojmo (Moravie): Inv. Archéol. en Tchécoslovaquie, p. 66-67.

Trogmayer, O., 1968, A Körös-csoport barbotin kerámiajarol: Archaeol. Ertesitö, v. 95,

p. 6-12.
Zbenovic, V. G., 1968, Keramika usativs'kogo tipu: Archeologija (Kiev), v. 21, p. 50-78. 